\title{
The Tilapia Agrifood-Chain from a Sociopoietic Territorial Approach: A Theoretical Proposal
}

\author{
Verónica Lango-Reynoso ${ }^{1}$, Juan L. Reta-Mendiola ${ }^{1}$, Felipe Gallardo López ${ }^{1}$, Fabiola Lango-Reynoso ${ }^{3}$, \\ Katia A. Figueroa-Rodríguez ${ }^{2}$ \& Alberto Asiain-Hoyos ${ }^{1}$ \\ ${ }^{1}$ Colegio de Postgraduados, Campus Veracruz, Manlio Fabio Altamirano, Veracruz, México \\ ${ }^{2}$ Colegio de Postgraduados, Campus Córdoba, Amatlán de los Reyes, Veracruz, México \\ ${ }^{3}$ Instituto Tecnológico de Boca del Río, Boca del Río, Veracruz, México \\ Correspondence: Juan L. Reta-Mendiola, Colegio de Postgraduados, Campus Veracruz, Manlio Fabio \\ Altamirano, Apartado Postal 421, Veracruz, México. Tel: 52-229-201-0770. E-mail: jretam@colpos.mx
}

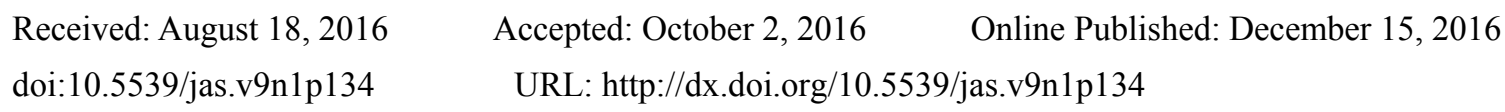

The research is financed by Consejo Nacional de Ciencia y Tecnología, Colegio de Postgraduados, Campus Veracruz, Instituto de Desarrollo Social \& Instituto Nacional de la Pesca.

\begin{abstract}
In the state of Veracruz, Mexico, the performance of the Tilapia (Oreochromis spp.) production system in the domestic market has been declining. Recent production results are lower than those presented in 1999, revealing that the production model adopted and used since 2001 is ineffective as a development strategy. The reason for the failure is that the model considers the technological production process as the central element of aquacultural competitiveness, without considering that production practices, marketing and consumption of goods are performed by individuals who decide and control their actions and are motivated by the values shared with their social group. This interpretation reveals the need for a new complementary conceptual framework, considering the system of production and consumption as a social self-referencing system. Thus, in this article, a model of an agricultural food-chain with a sociopoietic territorial focus on the development of the aquaculture subsector is outlined. The model is based on constructs having the following theoretical dichotomies: territorial agrifood, neo-institutional business, sociopoiesis and individual motivation.
\end{abstract}

Keywords: aquaculture, production chain, innovation, motivational values, product system

\section{Introduction}

The performance of the Tilapia (Oreochromis spp.) production system in the state of Veracruz, Mexico, has been declining in the domestic market, despite the investment of 3877.02 million MXN during 2014 and 2015 (Note 1) whose aim was to strengthen the physical, human and technological capital that would support this particular economic system (SHCP, 2016).

The production data show a declining annual growth rate of $-0.5 \%$ in 2014 , a loss of $3.98 \%$ during the period 2011 to 2013, and a market deficit of 37\% in 2013 (Note 2) (CONAPESCA, 2011, 2012, 2013, 2014; Rangel-López et al., 2014). This information reveals that the contemporary aquacultural model did not develop competitive tilapia farmers capable of meeting the commercial opportunities in Mexico made since the late twentieth century (Note 3) in terms of imports of frozen product (Ceja, 2009).

The Supply Chain model promoted by the Mexican Government considers this primary subsector as an exporter of agro-industrial goods, and which coordinates production and marketing through a structural and decision-making group called Tilapia Product System Committee (Note 4) (Diario Oficial de la Federación, 2001). Although this organization is presented at two levels in Mexico, national and state, the state of Veracruz, similar to other tilapia-producing states, cannot be inserted homogeneously into international agrifood economic dynamics (Gutman \& Gorenstein, 2003). Consequently, tilapia producers choose to act as individual agents in their quest for profit maximization (Kreps, 1990) coordinated through free market fluctuation (Gandlgruber, 2004). 
The regulatory requirement for tilapia farmers, is established by a State policy (Morales, 2000) which adopted an exogenous economic logic having particular values (Schwartz, 1994) that prevented them from leveraging their social structure (Penrose, 2003) and acting as a cooperative organization capable of taking collective action (Ostrom, Ahn, \& Olivares, 2003).

From the various models of agricultural production chains (Davis \& Goldberg, 1957), recent research has focused on different technological aspects of their performance (Leonardo, Bijman, \& Slingerland, 2015), unfortunately forgetting that production practices, marketing and consumption of agricultural products are made by people who control their actions based on their desires and preferences from memory (Note 5) of the society in which they lived (Bustillo et al., 2009; Casanova-Pérez et al., 2015a; Martínez-Dávila \& Bustillo-García, 2010).

To understand these phenomena, a complementary framework founded on the methodological basis of food-chain models and their theoretical frameworks is necessary (Cuevas, 2010; José Muchnik, Requier-Desjardins, Sautier, \& Touzard, 2007), as well as the use of third generation systems theories (Martínez-Dávila \& Bustillo-García, 2010). This approach is consistent with the historical complexity of agriculture and the prevalence of social reproduction in the origin of agricultural production organization (Casanova-Pérez et al., 2015a).

In this article, we present a representative conceptual model of the territorial production-consumption system of Tilapia, based on the review, analysis and synthesis of bibliographic information and empirical evidence. For its construction, the theoretical framework of the theories and concepts of food-chain models (Cuevas, 2010), agrifood systems (José Muchnik et al., 2007) the theory of neo-institutional business (Penrose, 2003), the sociopoietic systems theory (Arnold-Cathalifaud, 2008), and the universal system of motivational values are included (Schwartz, 2006).

This viewpoint identifies the origin of the dysfunctions in Tilapia aquaculture production system in a diferent dimension compared to the traditional use (Note 6) (Vivanco, Martínez, \& Taddei, 2010), visualizing the chain as a complex social phenomenon self-referenced by cultural aspects (Luhmann, 1998), such as motivational values.

\subsection{Agricultural Business Context}

Logical positivism has influenced economic thinkers of the twentieth century (Landreth, Colander, \& Rabasco, 2006), establishing neo-classical capitalism using empirical-deductive postulates (Note 7). Based on econometrics and general laws, we can explain agricultural economic characteristics (Ballestero, 2003) from the end of the twentieth century until today (Note 8) (Bergalli, 2005).

Under this economic rhetoric, industrialized countries have established neo-liberal economic policies (Friedman, 2006), mimicked with few innovative components from other countries (Fajnzylber, 1995) where structural adjustments were made to ensure modernization (Liverman \& Vilas, 2006). This structural transformation increased agricultural risk (Note 9) to global society (Costas, 2013). The neo-capitalist critics showed that the neo-liberal assumptions did not reflect agricultural reality (Lawrence, 2009) due to the complexity of the interrelations (Luhmann, 1998) (Table 1). Thus, analytical models and interpretations were included from institutions to counter the risk created by opening economies to a global environment (Luhmann, 1998).

Table 1. Assumptions of neo-liberal and institutionalist economics

\begin{tabular}{|c|c|}
\hline Neo-liberal & Neo-institutionalist \\
\hline Absence of transaction costs in perfect markets. & $\begin{array}{l}\text { Institutions (cooperative, firms or organizations) were created to } \\
\text { reduce transaction costs from market failures. }\end{array}$ \\
\hline $\begin{array}{l}\text { To achieve maximum benefits, neo-classical firms } \\
\text { behave as black box systems where inputs are } \\
\text { converted to products for market. }\end{array}$ & $\begin{array}{l}\text { Institutions explain how they are organized to transform inputs } \\
\text { into finished products for maximum benefits. }\end{array}$ \\
\hline Explains how pricing is conducted. & $\begin{array}{l}\text { Explains the basis of individual purchase decisions, and the } \\
\text { infrastructure that keeps the market and companies generating } \\
\text { economic activity. }\end{array}$ \\
\hline
\end{tabular}

Sources: Veblen (1945), Demsetz (1983), Coase (1996), Sykuta and Chaddad (1999).

Advanced industrial economies of the European Union's economic policy redefined economic policy and produced a model of agricultural development with fewer institutions (North, 1994). Neo-institutionalism 
proposed a regulatory and organizational framework for a better distribution of the benefits and risks of market integration through rational social management and reduction of organizational burden of productive activity of the State (DiMaggio \& Powell, 1991).

On this basis the desectorialización of agriculture was redefined, providing greater involvement of multiple actors of agricultural development (Luhmann, 1998) under strategic, commercial and information guidelines, as well as technological innovation and resource management (Costas, 2013). In sum, agribusiness in the twenty-first century is a complex global phenomenon, oriented towards obtaining economic benefits, which responds to the evolution of the worldview of the dominant society that developed it. Therefore, it is necessary to expand agriculture's vision itself by involving non-traditional aspects, but inherent to their nature, and to build its own representative and influential institutions in the sectorial politics of economic development and wealth generation for people engaged in this activity using their own resources.

\subsection{Evolution of the Agrifood-Chain Approach}

\subsubsection{Origin}

Production chains, as an abstraction of commercial agriculture, began developing more complex models. Historically, the focus on chains as applied to agriculture was promoted from the post-war period to ensure the supplies of raw materials and inputs from agribusiness in developed countries (Cook \& Chaddad, 2000).

Initially, the organization of agricultural production was studied under North American agricultural capitalist perspectives. Davis and Goldberg (1957) broadened the vision on agriculture with the "Agribusiness Commodity System" model, referred to as an aggregate of subsystems involving all production-commercialization operations for an agricultural product industry, and the "Subsector Approach", used to analytically describe the productive subsystems (Cook \& Chaddad, 2000).

Given the limitations of "Agribusiness" at explaining the forces influencing agricultural structure and dynamics, and their static and deductive approaches (Da Silva, 1994), models were generated from other economic schools to better explain this phenomenon (Caldentey, 2003). The fundamental French agrarian perspective is based the chain concept of Louis Malassis (1968) ("Systèmes Agro-alimentaires and Fillière Alimentaire") as a tool for the analysis of physical flows and interrelationships in agrifood products throughout all their production activities. This instrument evolved into the "Fillière de Production" when it included market satisfaction and its complex relationships (Lesage, 1984).

Early chain models were built on different visions of agricultural business from the neo-liberal, neo-classical, and institutional schools. All were destined to visualize the implicit interdisciplinary complexity in agroindustrial systems established to meet the rapid increase in demand for food in the dominant countries during the post-war period. Subsequent models evolved according to change in economic theory and these industrial production models were diffused to peripheral countries.

\subsubsection{Evolution}

In the 1980s, the US industrial sector coined the term "Supply Chain" to describe the process providing supplies focused on maximizing agroindustrial assembly (Shukla et al., 2011). Porter (1985), a business/economics researcher, introduced the model "Value Chain" to describe the process of generating product value through the relationships among industrial operational activities. When this model was applied to agricultural production, it referred to activities aligned through strategic alliances among companies, a necessity for products to flow from production to distribution (Peña et al., 2008).

During the 1990s in France, the Agrifood System (AS) was reinterpreted as an institution. In this system, the chains interacted as a logistics distribution unit covering all phases using networks of companies with technical and organizational efficiency (Morales, 2000); agency (Note 10) and convention (Note 11) theories explained their business operation and hierarchical coordination (Caldentey, 2003). The AS was distinguished as a productive process with high technological development that begins with raw material production and ends with the final consumer, thus requiring greater specialization and complex inter-organization (Morales, 2000).

In 1996, under the crisis in rural societies, the fundamentals of Local Food Systems (LFS) and "Milieu" (Local Innovation Systems) from the French school were proposed (Muchnik et al., 2007). This multidisciplinary system was integrated with production organizations and associated territorial services aspiring to adaptively compete through innovation and socioeconomic communication focused on local organizations having quality and social organization (Muchnik \& Sautier, 1998). 
The agrifood-chain model was rescued to distinguish agricultural food production within agribusiness (Cuevas, 2011), and incorporated the Value Chain to identify competitive advantages among the links. When necessary to compete in the market, value was created through joint operations, transformations, agents and markets sustained by physical and economic flows (Tallec \& Bockel, 2005).

The diversity of conceptual models that exist on the production and consumption of agricultural goods is preserved as an axis in open systemic models attempting to describe the phenomenon from the interests of the dominant economic schools. This diversity allows for choices that better represent the characteristics and purposes of capital accumulation, and growth of business organizations or territorial development, even including some models having features that can enrich other compatible models.

Neo-institutional economics focuses on the organization of food and agribusiness subsystems that counteract market forces which restrict trade, including agricultural actors with limited resources (Flores, 2013). The agrifood-chain model represents the production structure and localized food systems through competitiveness of the chain based on the resources within a defined territory. A selected model must respond to historical societal developments as they spread.

\subsection{Agrifood-Chain Trends Following Business/Economic Theory}

A food-chain is primarily considered as a hierarchical institution (Williamson, 2009) organized as a larger system articulated by subsystems with their own elements. The chain is composed of productive links that bring together companies specializing in carrying out each stage of production of a good (Note 12).

If we consider that a group of companies form the chain, then one company is a fraction of the chain containing a link (Mandelbrot, 1997). Therefore, the behavior of a company is reflected in the behavior of the chain, yet chain performance, understood as a system, is not measured by the performance of any one company. The performance is a retroactive emergent quality, a product of the synergies arising from chain organization acting on businesses (Morin, 1995). Given the chain is a unit of observation and analysis of the production and consumption of an agricultural good, then the theory of institutional business/economics can be employed to understand how the management of company resources (Table 2) influences the competitiveness of the chain.

Table 2. Agrifood-chain resources

\begin{tabular}{|c|c|c|c|}
\hline Origin & Types & Category & Resources \\
\hline \multirow[t]{12}{*}{ Internal } & Tangible & Products & Human resource managers \\
\hline & & & Administrative resources \\
\hline & & & Economic resources \\
\hline & & & Physical resources \\
\hline & & & Productive human resources \\
\hline & & & Technological resources \\
\hline & & & Market resources \\
\hline & Intangible & Relational & Organizational coordination \\
\hline & & & Production coordination \\
\hline & & & Market coordination \\
\hline & & Capacities & Cognitive capacity \\
\hline & & & Learning capacity \\
\hline \multirow[t]{6}{*}{ External } & Tangible & Production factors & Economic \\
\hline & & & Human resources \\
\hline & & & Technology \\
\hline & Intangible & Outreach & Professionalizing \\
\hline & & & Virtual support network \\
\hline & & & Unions \\
\hline
\end{tabular}

Sources: modified from Penrose (1995) and (Nooteboom, 2009).

The company integrates production agents under one contract (Powell, 2003) as an option for coordination in relation to the market and its pricing mechanism (Coase, 1994). Integration depends on the relationship between 
the costs of buying or producing a good to reduce transaction costs and increase profits. An integrated enterprise is transformed into a system of relations that require a management body (Coase, 1996) (Note 13) responsible for the production and development of adaptive capacities and efficiency in transaction costs (Gandlgruber, 2010).

The company is engaged in the market through the coordination of prices or production (Coase, 1996). The company is competitive and unique via the productive coordination that exists when management uses and combines its resources (Penrose, 2003) to synchronize environmental needs with responsiveness (García \& Taboada, 2012). Relational resources or inter-organizational collaborative links are part of the intangible internal resources of the company that can focus as a strategy for growth or maintenance (Williamson, 2009).

A command structure or organizational framework aimed at reducing transaction costs (Williamson, 1994) promotes the integration of work teams formed by agents or companies willing to sign an agreement to collaborate (contracts, licenses, franchises, mergers or strategic alliances) in the production by the company (Demsetz, 1997).

The company as a command structure facilitates coordination, monitoring, and dispute resolution to assist in decision-making and stability of contractual relations for production (Williamson, 2009). Its capacity for adjustment depends on the alignment of the structure with transactions (Note 14) that, together with their other accumulated capacities, distinguish it. Such capacities are related to skills, knowledge, strategies, human resources and materials, cooperative behavior and learning (Teece \& Pisano, 1994).

The organization of the company (Note 15) depends on its command structures and the behaviors of its individuals defined by the specificity of their actions, the frequency of transactions, and uncertainty (Williamson, 2009). Companies differ in their direction and ability of the employer to use its idiosyncratic knowledge in solving organizational problems. Its limit on growth depends on its ability to develop collaborative partnerships within and outside the organization (García \& Taboada, 2012). To increase income by satisfying the need to achieve, gather productive resources, and address inadequate capacities, the company directives use inter-business agreements as a hybrid form of management (Williamson, 2009) defined in terms of the capacity, resources, strategy, and vision of the cooperating companies (Penrose, 2003).

In short, from the perspective presented above, a chain is a productive socio-economic institution linking a group of companies. This view allows for systematization of the chain as a large company that brings together various organizations specialized in one phase of the production process of a commodity, and this is accomplished through cooperative inter-company agreements focused on the coordination of resources to reduce economic transaction costs.

As with any large company, the chain requires a governing body to be aware of what happens in agricultural markets, and to have an internal structure that promotes the alignment of production activities with the requirements of the same. In this perspective, to reduce market uncertainty and promote actions aimed at achieving competitiveness, it is indispensable to guide individual and group behavior of the chain to form an environment for strategic planning. To achieve this corporate vision, chains require an internal environment that fosters team-work, which is achieved when people who run businesses share a culture of cooperative work (Alchian \& Demsetz, 2009).

\subsection{Motivational Trends in an Agrifood-Chain}

The main argument about the importance of social representation for organizations (Note 16) (Arnold-Cathalifaud, 2008) lies in determining their attitude towards the adoption or rejection of organizational strategies and related development with its growth or decline (Parales-Quenza \& Vizcaíno-Gutiérrez, 2007). The way they see the world and act in it is stablish by the share beliefs of the society in which the organization evolves (Abric, 1984) is reflected in values, expressed as preferences and expectations (Parales-Quenza \& Vizcaíno-Gutiérrez, 2007) that guide their habits, rules, patterns of behavior and learning, individual behavior, idiosyncratic knowledge, and business insight (García \& Taboada, 2012).

The placement of values into the lives of individuals or groups is explained from its system requirements (Parsons, 2013). At the base, the physiological needs are followed by social needs and ultimately personal fulfillment (Maslow, 1970). Considering that values are the framework of individual behavior leading towards the satisfaction of needs, and that it is possible to differentiate individuals or social groups (Castro \& Nader, 2006), then values serve as predictive frameworks for variations in behavior, and individual interests and attitudes (Luhmann, 2006). 
In the model presented by Schwartz, (2006), "Portrait Values Questionnaire", the values are trans-situational goals, variables with degrees of importance, guiding the life and behavior of an individual or a social group. Values exist in this system underlying all cultures, grouped in contrasting dimensions oriented toward promotion of personal interests in collective function (Self-transcendence), prioritizing self-interests (Self-enhancement), safety and order (Conservation), and independence of actions and thoughts (Openness to change). Together, these groups of values define collectivist (Note 17), individualistic (Note 18), or mixed associations of social and cultural aspects (Figure 1).

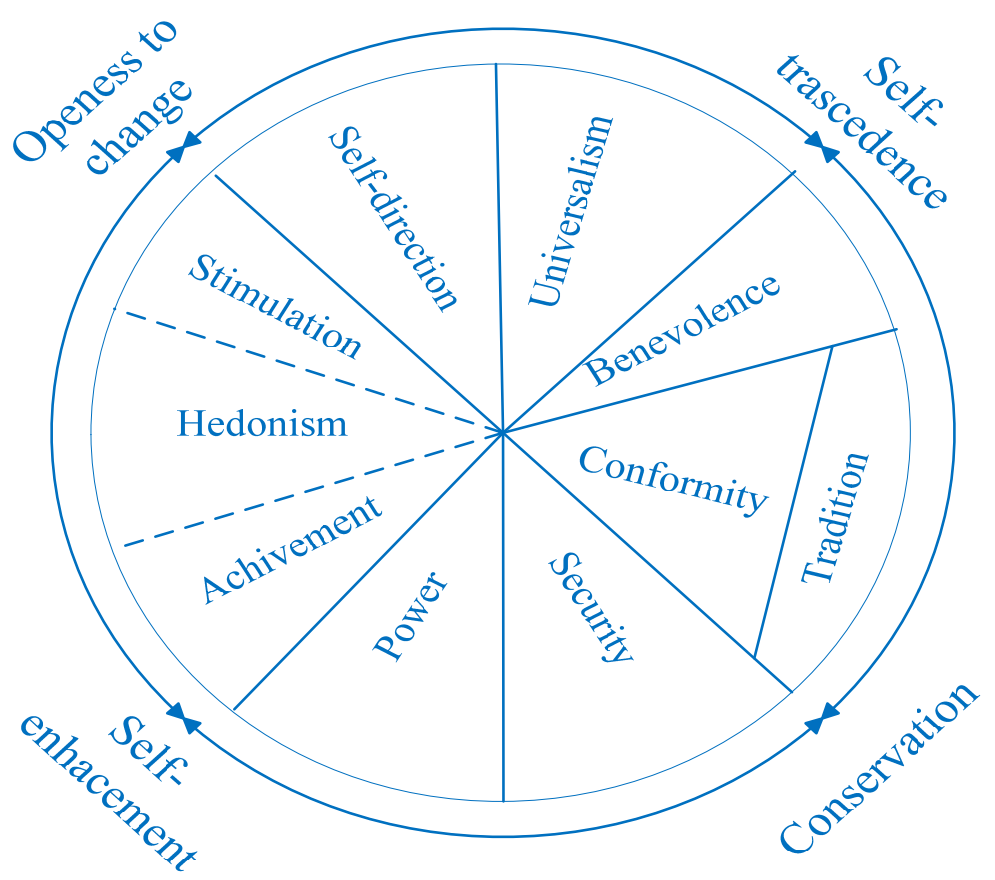

Figure 1. Theoretical relational model of motivational values

Source: Schwartz (2003).

For Schwartz, (2006), the values are personal and group responses to biological needs, coordination of social actions, and group function and survival. Thus, in an agrifood-chain motivational values can be identified that guide actors toward establishing chain organization with the companies as components (Alexander \& Colomy, 1990). Based on the identified values, the social group to which the actors belong designs motivating incentives to change individual attitudes and behaviors towards a cooperative organization, such as strategic alliances.

In a culture that values individuality, coinciding with the values of the predominant economic system, power, achievement and hedonism also are valued, making it difficult for people to accept a business growth strategy based on joint work (Schwartz, 2006). Therefore, to encourage cooperation, actors must offer members additional rewards to benefit the chain, and these achievements will allow them to acquire what they value as individuals (Olson, 1965).

Motivational values are a guide for actions occurring within the chain that reflect individual influence on system behavior. To change actions of the actors towards business growth, we must recognize the motives that drive changes in attitude and behavior towards an intervention that capitalizes on its social capital. If the chain does not value team-work, then the introduction of new values will modify knowledge on partnerships from within their cultural environment.

\subsection{Social Behavior in an Agrifood-Chain}

The research of social and cultural systems developed by Luhmann (1998) focuses on systems that involve human interactions organized by sense (Arnold, 1989). Here, evolution occurs through historical reflexive processes, including beliefs and values, nonexistent in natural systems (Hadis et al., 1976). Among these systems are the societal, organizational, interactional and group (Luhmann, 1998). 
This theoretical development is a comparative approach away from the traditional systemic notions applied to the study of society and culture (Arnold-Cathalifaud, 2008), which visualize the problems of contemporary society with the concepts of functional equivalents (Merton, 1968) and contingent functional social structures (Arnold, 1989).

Under this view, society is historically located in a territory defined by its linguistic and cultural system, and is interpreted as a complex self-referencing system that is naturally closed (Martínez-Dávila \& Bustillo-García, 2010). Such conditions reduce the complexity created by the range of their possible responses to environmental pressures, and meet their basic needs of self-reproduction with uninterrupted historical differentiation of autonomous hierarchical functional subsystems (Figure 2), but interdependent on the scale of global society (Luhmann, 1998).

Among the functional systems, the economic system is regulated by money exchange for goods obtained from specialized production systems regulated by capital. This system exists in geographical areas oriented toward agrifood systems (Luhmann, 2013), where they are responsible for the generation of food from production to consumption (Thorpe \& Bennett, 2004). The process is distributed among several specific subsystems identified by the agricultural production system and interpreted as an agroecosystem (AES) to the consumer system (Figure 2) (Martínez-Dávila \& Bustillo-García, 2010).

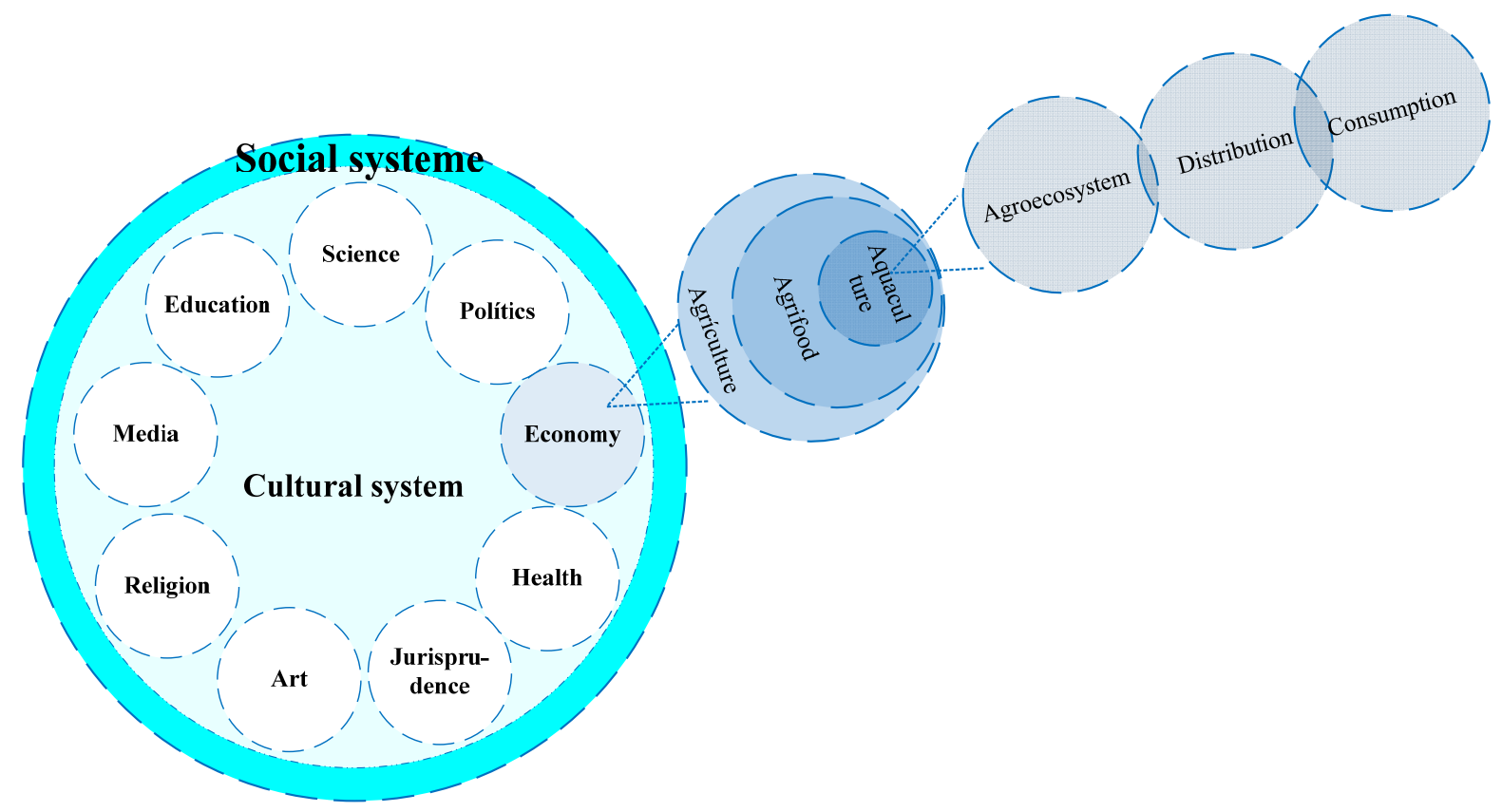

Figure 2. Functional societal systems

Note. Modified from Martínez-Dávila and Bustillo-García (2010).

The autopoiesis applicable to social organizations is known as sociopoiesis. Out of the functional subsystems arose organizational systems that performed production differentiation through the mobilization, orientation and integration of activities necessary to achieve the goal of the functional subsystem (Arnold-Cathalifaud, 2008). Society organized the agrifood system and its subsystems to maintain and reproduce itself by meeting the basic human need for food through its availability and accessibility which is managed by organizations related to the production and consumption of agricultural products (Casanova-Pérez et al., 2015a).

Sociopoiesis permits an understanding of the social reproduction that forms functional systems that meet the basic needs of society. As societal complexity increases, these systems reproduce in an effort to reduce the complexity (Luhmann, 2013). The economic system satisfies the need for food by a food product from a production process regulated by capital. From the agricultural ecosystem, through other systems for transport, marketing and consumption of an aquaculture product, access and availability can be acquired which are regulated by societal demand. Thus, an aquaculture food-chain can be analyzed as a sociopoietic system. 


\subsection{The Chain as a Model for Agricultural Development in México}

In Mexico, the concept of a Production Chain arose in the mid-1970s in work performed for the analysis of agribusiness systems (Vigorito, 1977). Under the influence of the United Nations Economic Commission for Latin America and the Caribbean (ECLAC), the Agrifood System was described as the unit of analysis for economic reproduction and was characterized in order to process agroindustrial transformation and property structures (Morales, 2000).

During the 1980s, researchers disseminated and adapted the model according to their political-economic trend and the type of end-product from the chain. Agroindustrial chains, supply chains, agroindustrial systems, production chains, or production structures were designed (Casar \& Ros, 1983; Loría, 2009). Their links were identified with the production, processing, distribution and consumption of an agricultural good, including credit support services, marketing, and production technology (Arroyo, 1986).

The globalizing economy attracted the interest of social scientists to analyze the agroindustrial structure in Mexico. This work was performed to determine the status of important agricultural sectors (Maclas, 1999), where the structure of the agroindustrial chain was modified and its operation focused on quality control of the product for export without considering distribution and consumption (Note 19). In this approach, they only included the links of production and processing, although they acknowledged relations with input from producers and assemblers (Rodríguez, 1999). After the year 2000, the Production Chain model was used regularly to understand the various industries involved in the development of an agricultural product (González, 2002).

The Production Chain model spread within the agricultural sector as a tool of observation and analysis of production-consumption, and became widespread as a tool of production organization for the globalist economic development model implemented in Mexico under the influence of its main trading partners.

\subsubsection{Regulatory Base}

Contemporary national economic policy is recognized in the production chain as an element for analysis and management of agricultural production structure, and is aimed at increasing productivity, profitability and competitiveness. The Sustainable Rural Development Law (2001) refers to this as the production-consumption chain including the production process of an agricultural or agroindustrial good in rural areas (Diario Oficial de la Federación, 2001). This model is intended to create the conditions for introducing to the world market competitive agricultural products by integrating agents and additional value to agroindustry.

The neo-classical capitalist model of Agribusiness is perceived as the predecessor to the Production Systems (PS) model, referred by Goldberg (1979) as Product Systems, which aims to meet the nutritional needs of consumers based on their lifestyle. In PS, participants in production, marketing, farming supply and storage, and entities and organizations that affect and coordinate goods production and distribution are integrated (Diario Oficial de la Federación, 2001).

The PS is a legal entity created to legally recognize the existence of the production chain and is a form of organization of agricultural production. It is conceived as a set of elements and concurrent agents of production processes for agricultural products, which maintain the overall structure of the supply chain model (Diario Oficial de la Federación, 2001). For operational purposes, the Secretary of Agriculture, Livestock, Rural Development, Fisheries and Food considers both terms equivalent, yet they are not because the first is a legal model and the second is a conceptual model representing the same reality.

The PS model includes a governing body related with other entities responsible for economic policy. The Production Systems Committee (PSC), comprised of representatives of the links in the production chain, is the legal entity of the PS which manages the planning and organization of production (forms of coordination), integration of links (agreements or strategic alliances) and commercial product protection.

The PS and PSC were created to strengthen national food production of eleven basic strategic commodities such as fish, including tilapia, therefore only the PSC was developed at a national scale with representatives from each state for each product. The state PSC in collaboration with the respective Rural Development District are responsible for developing strategies to strengthen productivity and competitiveness of the chain links located in its territory. The strategies involve materials management to support production, social organization, and development of marketing strategies, technology training, business development, and technological development (Diario Oficial de la Federación, 2001).

The full and effective framework proposed for chains is not recognized in one paragraph; between sections and articles of the Law are the elements that describe their methodology. This legal framework forms the foundation 
of strategic planning aimed at the articulation of the chain, which shows that the production chain is the responsibility of the PSC.

Based on the logic of global industries, the production chain model is valid, operable, and easy to understand and can incorporate elements according to its perspective, even Law facilitates social organization for productive purposes. Thus, actors can take action to strengthen the PS, the PSC, and the chain itself for the benefit of sectorial and territorial development.

Therefore, this model is capable of organizing agricultural production within a free market economy where actors are homogeneous, are owners of the means of production, where information flows throughout the entire system, and economic benefit is always pursued through the pricing system; a situation contrary to what exists in Mexico. Only large-scale agricultural enterprises competitively incorporate international trade, causing a deficit in the trade balance due to the loss of national markets for agricultural, horticultural, fruit, livestock, fishery and aquaculture products (Ayala Garay et al., 2011; SAT et al., 2016). In particular, national aquaculture production of tilapia is fighting a strong commercial battle against imported products; if a primary product is not competitive, the conservation of its domestic market is at risk.

\subsection{Description of the Tilapia Agrifood-Chain}

Considering that the aim of aquaculture is growing organisms for human consumption in an aquatic environment, it exists within the collective of agro-operations (Engle \& Stone, 2005), and its production process (Jensen et al., 2010) can be analyzed with a systemic approach. The Tilapia Agrifood-Chain (TAC) involves an interdependent group of agents working together to bring their products from the aquaculture system or agroecosystem to the consumer (Thorpe \& Bennett, 2004). Tilapia is an aquaculture good that is sold in different markets and in different forms (Engle \& Stone, 2005), so the analytical model and chain organization vary according to production complexity (See Appendix A).

The chains for high consumption products (commodities) focus on the production, processing and distribution of merchandise for export (Gibbon, 2001), and involve a network of agents and complex relationships with coordinated management and efficiency to meet international market needs and regulations. Its products, whole frozen tilapia, frozen fillets, and fresh fillets, provide a dynamic flow on the international market by increasing demand related to its low sales prices (Young \& Muir, 2002).

The chain of high-quality products focuses on increasing the value of prime materials from the aquaculture facility to the consumer's table (Jensen et al., 2010). It involves companies, organizations and related institutions by focusing on agreements to increase the competitiveness of the chain through strategic resource management (Jespersen et al., 2014). Processed tilapia products with export quality and high sales prices target specialized markets (Young \& Muir, 2002).

The fresh aquaculture products chain was developed at national, regional, and local levels (GLOBEFISH, 2014). Its production flow, biological input-production-processing-marketing-consumption, characterize its structure (Reta et al., 2007). For these chains, the primary inputs are the hatcheries, and product quality is heterogeneous due to the technological diversity of its production systems (Hernández et al., 2002). The value that is added to whole tilapia, refrigerated or on ice, is limited to filleting or artisanal deboning (Vivanco et al., 2010), and their sales prices vary according to quality and demand (Watanabe et al., 2002).

Given the nature of the aquaculture products offered live in regional markets (Thapa, Dey, \& Engle, 2015), the production system is a production chain that behaves like a value chain. Fish must be maintained under optimal conditions, physically and biologically, until they are purchased by consumers, and thus considered as high quality products (Young \& Muir, 2002), and this requires a specialized technology base that is reflected in a high sales price for fresh animal produce. The transport system is considered as a link chain, not a service due to its importance in the process (Puduri et al., 2011). In the marketing link it includes the use of aquaculture systems to maintain and display living organisms in supermarkets, markets, and restaurants (Thapa et al., 2015), as well as other points of urban and rural sale (Lango-Reynoso et al., 2015). The production process is based on an organizational model where the building of partnerships among members of the links is intended to coordinate chain resources to meet the needs of the product market.

Aquaculture chains follow the general model established by FAO (Piñones, Acosta, \& Tartanac, 2006), where their differences are related to the final product and its productive organization. The value chain is distinguished from the supply chain according to the degree of integration and coordination among the actors, as well as differentiation and competitiveness (Note 20) achieved by managing its resources (Rugman \& Verbeke, 2002). 
Thus, the developmental stages of the tilapia aquaculture chain are observed in its organizational forms as a production chain, value chain, or supply chain.

\section{Methodology}

Research conceptual definitions were built within the aquaculture development framework, agrifood chain approach was used to describe Tilapia (Oreochromis spp.) production-consumption process.

To build the theoretical structure of the agrifood chain from the sociopoietic territorial approach, which pretends to explain the behavior of the commercial interchange processes between producers and traders of live tilapia, as part of the production consumption links, a deductive critical analysis was developed of the basic and secondary literature (Sautu et al., 2005), related with chain models and the general neo-institutional company theory, including autopoietic social systems, and motivational values, to link to the empirical evidence of corporate, motivational and social systems behaviors. Search sources were: JSTOR, Elsevier, Science Direct Freedom Collection, Taylor and Francis Group, and Google Academic.

From August 2011 to June 2016 a study case (Martínez, 2011) was established on the live tilapia selling points model. This technology was previously transferred by rural innovation processes (Reta et al., 2011) to a market network established at Sotavento region, Veracruz state, Mexico. The Study Case include social, technological, and economic aspects related to the network creation, operation and technical support, to outline performance.

\section{Results}

\subsection{Theoretical Proposal for the Tilapia Agrifood-Chain from a Sociopoietic Territorial Approach}

Given that an agrifood-chain is the link for consumption of an agricultural product, and according to the description of the agricultural ecosystem as an autopoietic unit (Martínez-Dávila \& Bustillo-García, 2010), we propose the Tilapia Agrifood-Chain using a Sociopoietic Territorial Approach (TAC/STA) as a functional social organization composed of specialized technological, economic, and human elements that distinguish and limit its environment. This organization is a closed structure of self-generated communications and relations which flow from energy, economics, materials, information, and services exchanges needed to go from the production to the consumption of an agricultural good (Figure 3).

The performance of the TAC/STA responds to the effect of interaction between decisional communications and components, rather than the addition of elements (Arnold, 1989). In its environment, situated in an area defined by its culture, is the society that created it, in addition to other specialized functional social systems that recognize and interact with equalities, differences, and hierarchical transversalities in economic, political, scientific, educational, and jurisprudence scope (Figure 2) (Arnold-Cathalifaud, 2008). Inside the environment also are productive actors or individuals controlling production systems, characterized as Psychic Systems (PS) (Note 21) (Casanova-Pérez et al., 2015b), who, through their knowledge of the environment and communicative abilities regarding perceived influence, through its self-reflexive, act to supply or disrupt the mechanisms responsible for recurrent and presupposed operational actions that maintain chain structure.

The cultural system of the territory (Luhmann, 2006), perceived by actors in the chain, influences the development of selective criteria or values used in decision-making process of individual consciousness systems about the characteristics of the information, that will be to communicated within the chain structure (Arnold-Cathalifaud, 2008). Such information refers to that which exists in the system environment regarding resource management of agricultural enterprises (Casanova-Pérez et al., 2015a; Penrose, 2003).

The cultural system of the territory (Luhmann, 2006), perceived by the actors in the chain, influences the development of selective criteria or values used in decision-making systems (Casanova-Pérez et al., 2015a; Penrose, 2003). 


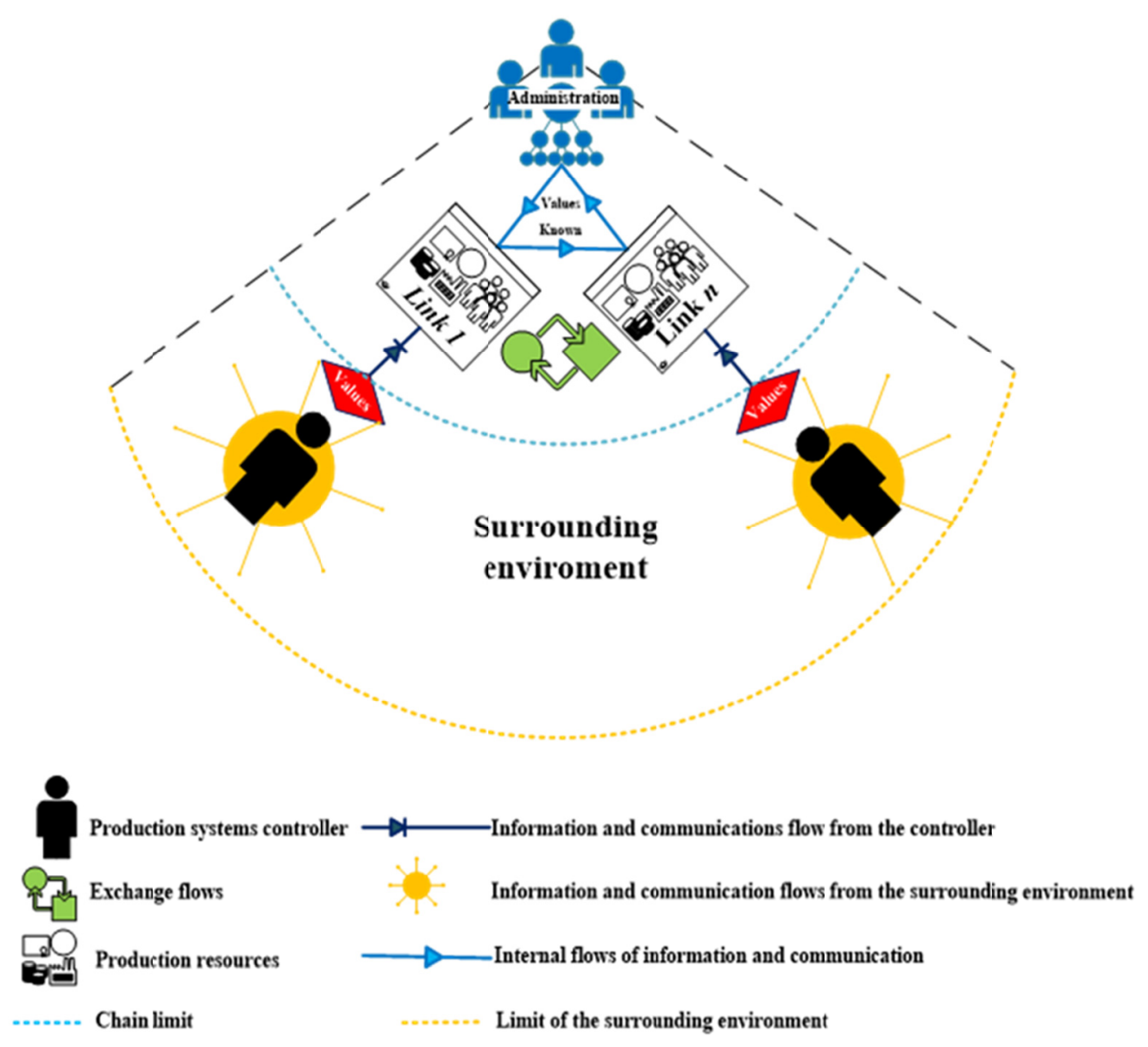

Figure 3. Conceptual diagram of an agrifood-chain using a sociopoietic territorial approach

When information comes to the chain, it is reproduced in a self-referential form, behaving like a recursive series of actions, which determine the cultural capital of the chain (Bourdieu, 1986). It manifests itself in the management practices of the elements or organization resources and exchanges of energy, materials and financial resources, necessary to achieve its social function, and to maintain its status of conservation, growth, or reduction, depending on the existing possibilities. A change in the status of the TAC/STA, in relation to the dynamics of its environment, is only generated by its structure, part of an empirical self-reflection process that accounts for its status and possibilities of accepting an exogenous innovation that maintains its operations and preserves system viability (Arnold-Cathalifaud, 2008).

The viability of the chain, reflected in its capacity of structural coupling to the demands of the market, is its ability to evolve through auto-interventions or innovations that strengthen its capacities to coordinate resources (Arnold-Cathalifaud, 2008; Penrose, 2003). However, such interventions can come from outside when they are discriminated against by rational choices of actors through appropriate interventions by agents of change (Arnold-Cathalifaud, 2008).

Acceptance of exogenous innovations related to collective actions in an organizational social system, such as alliances or partnerships, is conditioned by a payment which goes beyond social benefit (Olson \& Zeckhauser, 1966). The search for this benefit causes disturbances in the organizational continuum (Olson, 1965), so it is necessary to identify the nature of incentives to guide the choices of actors, who are subjected to innovation, toward acceptance and adoption (Knoke, 1988).

The formation of alliances among links of the TAC/STA can be seen as a communicative coordination structure with predictive capabilities (Nooteboom, 2009), and is an innovation tool whose members are conditioned by the interests of individuals to join (Knoke, 1988), responding to what they value as members of the society in which they developed (Coase, 1994). 
The cultural system lies in the production system environment and is made up of information communicated linguistically through a self-constructed collective memory, containing the values and beliefs that influence the attitudes and behaviors of the actors in relation to their social system (Willke, 1993).

Given that the system is a rational consciousness, which acts as a receiver and generator of information communicated linguistically between TAC and their environment (Casanova-Pérez et al., 2015a), coordination of system resources via partnerships should be instituted to achieve its social function and be perceived by actors as restrictive recursive actions.

In conclusion, an agrifood-chain is an autonomous body that reproduces itself through self-generated resources, thus its self-produced performance for its actions is equal to the state of its resources generated by information circulating on the network of human interactions that maintains organization structure. Motivational values of the people who transmit information to the communication structure guide all actions, including intervention, because they follow their natural direction.

\section{Discussion}

In the state of Veracruz, Mexico, the Tilapia Agrifood-Chain is composed of five links formed by specialized companies (Table 3) (Reta et al., 2007). Fresh tilapia, as its main product (Rangel-Lopez et al., 2014), does not compete with the price and presentation of products nationally, nor with imported tilapia, and thus has lost part of its market. The lack of competitiveness (North, 1994) is related to the low articulation of production among links, without which it is not possible to coordinate the resources and system capabilities (Arrow, 1969).

As a business strategy to increase the competitiveness of the Tilapia Agrifood-Chain based on its own resources and the nature of the territory, a network marketing of live tilapia was established at specified points of sale (Lango-Reynoso et al., 2015). Building partnerships between the links is necessary for quality and quantity, and to maintain product quality during its transit through the chain to meet the regional market (Table 4).

Table 3. Components of the Tilapia Agrifood-Chain in Veracruz, Mexico

\begin{tabular}{lllll}
\hline Links & Principal actors & Production factors & Exchange flows & Specialized functional systems \\
\hline Biological inputs & Producer of biological inputs & Natural resources & Economics & Financing \\
Nursery feeding & Tilapia producer & Economic capital & Materials & Government \\
Transportation & Transport & Production methods & Services & Input providers \\
Marketing & Marketer & Human resources & Energy & Education \\
Consumption & Consumer & Technological resources & Information & Research \\
& & Technical and scientific knowledge & & \\
\hline
\end{tabular}

Table 4. Trade issues between producers and marketers of live tilapia

\begin{tabular}{llll}
\hline Actors & Problem & Alternative Solution & Link requirements \\
\hline Marketers & Supply: & Wide range of suppliers & Stable production. \\
& $\begin{array}{l}\text { inconsistent supply volume and frequency, } \\
\text { variation in product quality (size, appearance, } \\
\text { health), high prices, lack of specialized } \\
\text { transportation service }\end{array}$ & $\begin{array}{l}\text { post-harvest practices. } \\
\text { Preferred prices without seasonal } \\
\text { variation. }\end{array}$ \\
& $\begin{array}{l}\text { Product delivery to the home. } \\
\text { Producers }\end{array}$ & $\begin{array}{l}\text { Sales: } \\
\text { Inconsistent demand in quantity and frequency } \\
\text { and seasonal production }\end{array}$ & $\begin{array}{l}\text { Volume and frequency are stable for } \\
\text { purchasing }\end{array}$ \\
\hline
\end{tabular}

Based on the performance of "Point of Sales of Live Tilapia" as a marketing strategy to increase the competitiveness of the agrifood-chain in the Sotavento region of the state of Veracruz (Lango-Reynoso et al., 2015), the system is not articulated. Thus, the system cannot be promoted and managed by its organization through cooperative agreements among the actors to coordinate their production resources and generate cognitive capacities and learning, which differs from other competing systems; strategies needed to maintain and grow the participating companies (Nooteboom, 2009). 
This chain is a functional system located in a defined territory, which is responsible for meeting the social demand for tilapia as a food product through an integrated network of relationships based on communication. This system is coupled to the social environment by a representative governing body of production agents (Arnold-Cathalifaud, 2008), formally established in the territory (Diario Oficial de la Federación, 2001) and called the Systems Committee for Tilapia Products (SCTP).

The actors involved (PS) influence decisions about management practices and organization of resources of the structure. Through interaction with other recognized functional systems in the environment (scientific, educational, financial, political and inputs), the PS receives information to turn it into knowledge transmitted as information on the structure of the chain and, once there, becomes shared knowledge that influences the behavior of the system. This is a recurring process with double contingency, because every productive and organizational action responds to a self-referred decision from the previous action, self-reproduced (Luhmann, 1998).

An innovation focused on the development of social capital (Ostrom \& Ahn, 2009) and use of endogenous resources in the chain (Muchnik \& Sautier, 1998) alters the traditional management practices and organization of its production resources (Penrose, 2003), and its competitive performance (Soosay, Hyland, \& Ferrer, 2008). These interventions are viable only when the functional structure of the chain is aware of its status through self-observation and self-recognition. This change will be achieved by entering new knowledge into the system through the exchange of information on cooperative work (Arnold-Cathalifaud, 2008) and production differentiation (Sankaran \& Suchitra, 2006).

To accept alliances prior to intervention, the structure recognizes motivational PS values (Schwartz, 2006) to design motivating stimuli to guide the collective action of innovation.

Recognizing that the social values of the chain actors motivate their decisions on the management of individual and collective resources (Schwartz, 2006), it follows that the PS involved are unknown to or inexperienced in the ways and means of collective work (Soosay et al., 2008). The value of a relational resource such as production structure alliances is that it does not take advantage of developing companies, or the chain, limiting their competitiveness.

Among the cultural (PS) and structural (SCTP) there are controversies that result in inefficiencies and even threats to the survival of aquaculture firms (Allaire \& Firsirotu, 1984). Resistance to change is reflected in traditional practices, hence the importance of teamwork is incipient and probably due to mistrust of joint work, the alleged loss of control in their companies due to collective work, and changes in power relations. To know and accept the idea of partnerships, they must satisfy their motivational needs beyond direct benefits and insist that there are strategic actions for their companies (Olson, 1965).

Culture (PS) can change interest in an organizational system (Denison, 1991). To accept an intervention, they must initially develop intervention strategies according to individual values. Afterwards, they can intervene in the proposed participatory change in the chain and its structure by spreading collective values. In an environment of cooperation and coordination of resources to improve competitiveness (Lado \& Wilson, 1994), the new chain values (cultural capital) will be part of their intangible resources (Bourdieu, 1986) and the foundation of its social capital (Note 22) (Ostrom \& Ahn, 2009) to benefit the production and market activity of the actors (García \& Taboada, 2012).

The design of the chain based on its cultural environment and endogenous resources allows for adoption among firms. Thus, the production sector will be politically representative and have management capacity to promote human, social and economic development in the region (IICA, 2010). Under this system (Note 23) the interweaving of necessary relations will develop for firms to grow by following regulatory and organizational standards for production actions and group values, thus laying the foundation for consensus decisions on activities for collective and individual benefit (Ostrom et al., 2003).

Given the agrifood-chain designed as an institution and then translated into an organized business, and that such actions can influence markets, politics and other institutions (Dossi \& Lissin, 2011), the system is able to establish formal rules, informal norms and their system application in order to provide the space necessary for economic activity (North, 1994).

\section{Conclusion}

In conclusion, the self-referencing social systems approach allows us to understand the state of the Tilapia Agrifood-Chain, and to recognize that the nature of the recurring actions taken to solve their business problems come from the shared culture within the territory in which it operates. They can only change their status by introducing new information to the structure formed by the communication network. Partnerships as a strategy 
for coordination of resources in the chain will only be accepted when people change their interests to benefit the collective.

Chain growth depends on the management of system resources independently of the individual and the achievement of an entrepreneurial culture. Values influence the decisions of the actors on management practices of its resources and capabilities, loss of markets, and the competitiveness of the aquaculture chain.

\section{References}

Abric, J. C. (1984). A theoretical and experimental approach to the study of social representations in a situation of interaction. In R. M. Far \& S. Moscovici (Eds.), Social representations (pp. 169-183). Cambridge: Cambridge University Press.

Alchian, A., \& Demsetz, H. (2009). Production, information costs, and economic organization. In R. S. Kroszner \& L. Putterman (Eds.), The Economic Nature of the Firm: A Reader (pp. 173-196). Cambridge University Press. http://dx.doi.org/10.1017/CBO9780511817410.015

Alexander, J. C., \& Colomy, P. (1990). Neofunctionalism today: reconstructing a theoretical tradition. In G. Ritzer (Ed.), Frontiers of social theory: The new syntheses (pp. 33-67). New York: Columbia University Press.

Allaire, Y., \& Firsirotu, M. E. (1984). Theories of organizational culture. Organization Studies, 5(3), 193-226. http://dx.doi.org/10.1177/017084068400500301

Arnold, M. (1989). Teoría de Sistemas. Nuevos Paradigmas: Enfoque de Niklas Luhmann. Revista Paraguaya de Sociología, 75(26), 1-56.

Arnold-Cathalifaud, M. (2008). Las organizaciones desde la teoría de los sistemas sociopoiéticos. Cinta de Moebio, 32, 90-108. http://dx.doi.org/10.5902/6383

Arroyo, G. (1986). La biotecnologia y el análisis de las cadenas o sistemas agro-alimentarios y agroindustriales. Revista Centroamericana de Economía, 19(25), 247-264.

Ayala Garay, A. V., Sangerman-Jarquín, D. M., Schwentesius Rindermann, R., Almaguer Vargas, G., Barrera, J., \& Luis, J. (2011). Determinación de la competitividad del sector agropecuario en México, 1980-2009. Revista Mexicana de Ciencias Agrícolas, 2(4), 501-514.

Ballestero, E. (2003). La economía agrícola: tendencias y horizontes. Revista Española de Estudios Agrosociales y Pesqueros, 200, 503-546.

Bergalli, R. (2005). Relaciones entre control social y globalización: Fordismo y disciplina. Post-fordismo y control punitivo. Sociologías, Porto Alegre, 7(13), 180-211. http://dx.doi.org/10.1590/s1517-4522200500 0100008

Bourdieu, P. (1986). The forms of capital. In J. Richardson (Ed.), Handbook of Theory and Research for the Sociology of Education (pp. 241-258). New York: Greenwood Publishing Group. http://dx.doi.org/10.1002/ 9780470755679.ch15

Bustillo, G. L., Martínez, D. J. P., Osorio, A. F., Salazar, L. S., González, A. I., \& Gallardo, L. F. (2009). Grado de sustentabilidad del desarrollo rural en productores de subsistencia, transicionales y empresariales, bajo un enfoque autopoiético. Revista Científica, 19(6), 650-658.

Caldentey, P. (2003). Neoinstitucionalismo y Economía Agroalimentaria. Contribuciones a la economía. Retrieved June 15, 2016, from http://www.eumed.net/ce/

Casanova-Pérez, L., Martínez-Dávila, J. P., López-Ortiz, S., Landeros-Sánchez, C., López-Romero, G., \& Peña-Olvera, B. (2015a). El agroecosistema comprendido desde la teoría de sistemas sociales autopoiéticos. Revista Mexicana de Ciencias Agrícolas, 6(4), 855-865.

Casanova-Pérez, L., Martínez-Dávila, J. P., López-Ortiz, S., Landeros-Sánchez, C., López-Romero, G., \& Peña-Olvera, B. (2015b). Enfoques del pensamiento complejo en el agroecosistema. Interciencia, 40(3), 210-216.

Casar, J. T., \& Ros, J. (1983). Problemas estructurales de la industrialización en México. Investigación Económica, 42(164), 153-186.

Castro, S. A., \& Nader, M. (2006). La evaluación de los valores humanos con el Portrait Values Questionnaire de Schwartz. Interdisciplinaria, 23(2), 155-174. 
Ceja, P. H. (2009). Estudio sobre: Evaluación de Medidas de Control a las Importaciones de Tilapia y sus Productos Mediante Medidas Arancelarias y la Aplicación Estricta de Procedimientos de Trazabilidad. México: SAGARPA/CONAPESCA.

Coase, R. H. (1994). La Empresa, el Mercado y la Ley. Madrid: Alianza editorial

Coase, R. H. (1996). La naturaleza de la empresa. In E. L. Suárez (Trans.), In O. Williamson \& S. Winter (Eds.), La Naturaleza de la Empresa: Orígenes, Evolución y Desarrollo (pp. 29-48). México: Fondo de Cultura Económica.

CONAPESCA. (2011). Anuario Estadistico de Pesca y Acuicultura. México: SAGARPA.

CONAPESCA. (2012). Anuario Estadístico de Pesca y Acuicultura. México: SAGARPA.

CONAPESCA. (2013). Anuario Estadístico de Pesca y Acuicultura. México: SAGARPA.

CONAPESCA. (2014). Anuario Estadístico de Pesca y Acuicultura. México: SAGARPA. Retrieved May 14, 2016, from http://www.conapesca.sagarpa.gob.mx/wb/cona/cona_anuario_estadistico_de_pesca

Cook, M. L., \& Chaddad, F. R. (2000). Agroindustrialization of the global agrifood economy: bridging development economics and agribusiness research. Agricultural Economics, 23(3), 207-218. http://dx.doi.org/10.1016/s0169-5150(00)00093-1

Costas, D. P. (2013). Agronegocios: Entre la Sociedad del Riesgo y el Neoliberalismo. Buenos Aires: Instituto de Investigaciones Gino Germani, Facultad de Ciencias Sociales, Universidad de Buenos Aires.

Cuevas, R. V. (2010). Análisis del enfoque de cadenas productivas en México. Textual, 56, 83-93.

Da Silva, J. G. (1994). Complejos agroindustriales y otros complejos. Agricultura y Sociedad, 72, 205-240.

Davis, J. H., \& Goldberg, R. A. (1957). A Concept of Agribusiness. Boston: Division of research. Graduate School of Business Administration. Harvard University.

Demsetz, H. (1997). La Economía de la Empresa. Madrid: Alianza Editorial.

Denison, D. (1991). Cultura Corporativa y Productividad Organizacional. Colombia: Editorial Legis

Diario Oficial de la Federación. (2001). Ley de Desarrollo Rural Sustentable (pp. 41-80). Secretaria de Agricultura Ganadería Desarrollo Rural Pesca y Alimentación. México.

DiMaggio, P. J., \& Powell, W. W. (1991). The New Institutionalism in Organizational Analysis (Vol. 17). United States of America: University of Chicago. Press Chicago, IL.

Dossi, M., \& Lissin, L. (2011). La acción empresarial organizada: Propuesta de abordaje para el estudio del empresariado. Revista Mexicana de Sociología, 73(3), 415-443.

Engle, C. R., \& Stone, N. M. (2005). Aquaculture: Production, Processing, Marketing. In W. G. Pond \& A. W. Bell (Eds.), Encyclopedia of Animal Science (Print) (pp. 48-51). New York: Marcel Dekker.

Fajnzylber, F. (1995). Latin American Development: From the "Black Box" to the "Empty Box." In B. H. Koo \& D. H. Perkins (Eds.), Social Capability and Long-Term Economic Growth (pp. 242-265). UK: Palgrave Macmillan. http://dx.doi.org/10.1007/978-1-349-13512-7_12

Flores, N. A. (2013). Diagnóstico de la Acuicultura de Recursos Limitados (AREL) y de la Acuicultura de la Micro y Pequeña Empresa (AMYPE) en América Latina (December Vol.). Roma: FAO.

Friedman, T. L. (2006). La Tierra es Plana. Madrid: Ediciones Martínez Roca.

Gandlgruber, B. (2010). Instituciones, Coordinación y Empresas: Análisis Económico más allá de Mercado y Estado (1st ed.). Barcelona: Anthropos Editorial. Universidad Autónoma Metropolitana.

Gandlgruber, B. B. (2004). Abir la caja negra: teorías de la empresa en la economía institucional. Análisis Económico, XIX(41), 19-58.

García, G. A., \& Taboada, I. E. L. (2012). Teoría de la empresa: las propuestas de Coase, Alchian y Demsetz, Williamson, Penrose y Nooteboom. Economía: Teoría y Práctica, 36, 9-42.

Gibbon, P. (2001). Upgrading primary production: A global commodity chain approach. World Development, 29(2), 345-363. http://dx.doi.org/10.1016/S0305-750X(00)00093-0

GLOBEFISH, H. (2014). Tilapia Highlights. Una Actualización Trimestral Sobre los Mercados Mundiales de Productos Pesqueros (Vol. 3, pp. 28-30). FAO/GLOBEFISH Highlights. 
Goldberg, R. A. (1979). El Enfoque de Sistemas y los Agribusiness. Cuadernos de Desarrollo Rural, Septiembre(1), 8-18.

González, M. L. M. (2002). La Industrialización en México (1st ed.). México: Universidad Nacional Autónoma de México. Instituto de Investigaciones Económicas. Miguel Ángel Porrúa.

Gutman, G. E., \& Gorenstein, S. (2003). Territorio y sistemas agroalimentarios. Enfoques conceptuales y dinámicas recientes en la Argentina. Desarrollo Económico, 42(68), 563-587. http://dx.doi.org/10.2307/ 3455905

Hadis, B. F., Berger, P. L., Luckmann, T., \& Hadis, B. F. (1976). La construcción social de la realidad. Desarrollo Económico, 16(60), 641. http://dx.doi.org/10.5944/rif.4.2005.5447

Hernández, M. M., Reta, M. J. L., Gallardo, L. F., \& Nava, T. M. E. (2002). Tipología de productores de mojarra tilapia (Oreochromis spp.): base para la formación de grupos de crecimiento productivo simultaneo (GCPS) en el Estado de Veracruz, México. Tropical and Subtropical Agroecosystems, 1(1), 13-19.

IICA. (2010). Desarrollo de los Agronegocios y la Agroindustria Rural en América Latina y el Caribe: Conceptos, Instrumentos y Casos de Cooperación Técnica. San José, Costa Rica: Instituto Interamericano de Cooperación para la Agricultura (IICA).

Jensen, T. K., Nielsen, J., Larsen, E. P., \& Clausen, J. (2010). The Fish Industry-Toward Supply Chain Modeling. Journal of Aquatic Food Product Technology, 19(3-4), 214-226. http://dx.doi.org/10.1080/ 10498850.2010 .508964

Jespersen, S. K., Kelling, I., Ponte, S., \& Kruijssen, F. (2014). What shapes food value chains? Lessons from aquaculture in Asia. Food policy, 49, 228-240. http://dx.doi.org/10.1016/j.foodpol.2014.08.004

Knoke, D. (1988). Incentives in collective action organizations. American Sociological Review, 53(3), $311-329$. http://dx.doi.org/10.2307/2095641

Kreps, D. (1990). Corporate Culture and Economic Theory. In J. Alt \& K. Shepsle (Eds.), Perspectives on Positive Political Economy (pp. 90-143). New York: Cambridge University Press. http://dx.doi.org/ 10.1017/cbo9780511571657.006

Lado, A. A., \& Wilson, M. C. (1994). Human resource systems and sustained competitive advantage: A competency-based perspective. Academy of Management Review, 19(4), 699-727. http://dx.doi.org/10.2307/ 258742

Landreth, H., Colander, D. C., \& Rabasco, E. (2006). Historia del Pensamiento Económico (4th ed.). España: McGraw Hill.

Lango-Reynoso, V., Reta-Mendiola, J. L., Asiain-Hoyos, A., Figueroa-Rodríguez, K. A., \& Lango-Reynoso, F. (2015). "Live Tilapia": Diversifying livelihoods for rural communities in México. Journal of Agricultural Science, 7(10), 101-112. http://dx.doi.org/10.5539/jas.v7n10p101

Lawrence, K. F. (2009). Reviewed Work: Absentee Ownership: Business Enterprise in Recent Times: The Case of by Thorstein Veblen. Political Science Quarterly, 39(3), 509-512. http://dx.doi.org/10.2307/2142605

Leonardo, W. J., Bijman, J., \& Slingerland, M. A. (2015). The Windmill Approach: Combining transaction cost economics and farming systems theory to analyse farmer participation in value chains. Outlook on Agriculture, 44(3), 207-214. http://dx.doi.org/10.5367/oa.2015.0212

Liverman, D. M., \& Vilas, S. (2006). Neoliberalism and the environment in Latin America. Annual Review of Environment and Resources, 31, 327-363. http://dx.doi.org/10.1146/annurev.energy.29.102403.140729

Loría, E. (2009). Sobre el lento crecimiento económico de México: una explicación estructural. Investigación Económica, 68(270), 37-68.

Luhmann, N. (1998). Sistemas Sociales: Lineamientos para una Teoría General (1st ed., Vol. 15). Anthropos Editorial.

Luhmann, N. (2006). La Sociedad de la Sociedad. México: Editoral Herder -Universidad Iberoamericana

Luhmann, N. (2013). La economía de la sociedad como sistema autopoiético. Revista Mad. Magister en Análisis Sistémico Aplicado a la Sociedad, 29, 1-25. http://dx.doi.org/10.5354/0718-0527.2013.27342

Maclas, A. A. (1999). Tendencias de la restructuración agroindustrial en la actividad lechera mexicana. In B. E. Martínez, M. A. Álvarez, H. L. A. Gracía \& M. de C. Del Valle (Eds.), Dinámica del sistema lechero mexicano en el marco regional y global (pp. 183-202). México D.F.: Plaza y Valdez Editores. 
Mandelbrot, B. (1997). La Geometría Fractal de la Naturaleza (2nd ed.). Barcelona: Tusquets Editores.

Martínez, C. P. C. (2011). El método de estudio de caso: Estrategia metodológica de la investigación científica. Pensamiento y Gestión, 20(Julio), 165-193.

Martínez-Dávila, J. P., \& Bustillo-García, L. (2010). La autopoiesis social del desarrollo rural sustentable. Interciencia, 35(3), 223-229.

Maslow, A. H. (1970). In J. Fadiman \& C. McReynolds (Eds.), Motivation and Personality (2nd ed.). New York: Harper \& Row.

Merton, R. K. (1968). Social Theory and Social Structure. New York: The Free Press.

Morales, E. A. (2000). Los principales enfoques teóricos y metodológicos formulados para analizar el sistema agroalimentario. Revista Agroalimentaria, 6(10), 75-88.

Morin, E. (1995). Introducción al Pensamiento Complejo (2nd ed.). Madrid: Editoral Gedisa.

Muchnik, J., \& Sautier, D. (1998). Systèmes Agro-alimentaire Localisés et Construction de Territoires. ATP CIRAD.

Muchnik, J., Requier-Desjardins, D., Sautier, D., \& Touzard, J. M. (2007). Systèmes agroalimentaires localisés. Economies et Sociétés AG, 29, 1465-1484.

Nooteboom, B. (2009). A Cognitive Theory of The Firm: Learning, Governance and Dynamic Capabilities. UK: Edward Elgar Publishing. http://dx.doi.org/10.4337/9781848447424

North, D. C. (1994). La evolución de las economías en el transcurso del tiempo. Revista de Historia Económica/Journal of Iberian and Latin American Economic History (Second Series), 12(03), 763-778. http://dx.doi.org/10.1017/s021261090000481x

Olson, M. (1965). The Logic of Collective Action: Public Goods and the Theory of Groups. United States of America: Harvard University Press.

Olson, M., \& Zeckhauser, R. (1966). An economic theory of alliances. The Review of Economics and Statistics, 48(3), 266-279. http://dx.doi.org/10.2307/1927082

Ostrom, E., \& Ahn, T. K. (2009). The meaning of social capital and its link to collective action. In G. T. Svendsen \& G. L. Svendsen (Eds.), Handbook of Social Capital: The Troika of Sociology, Political Science and Economics (pp. 17-35). USA: Edward Elgar Publishing. http://dx.doi.org/10.4337/97818484474 86.00008

Ostrom, E., Ahn, T. K., \& Olivares, C. (2003). Una perspectiva del capital social desde las ciencias sociales: Capital social y acción colectiva. Revista Mexicana de Sociología, 65(1), 155-233. http://dx.doi.org/10.2307/3541518

Parales-Quenza, C. J., \& Vizcaíno-Gutiérrez, M. (2007). Las relaciones entre actitudes y representaciones sociales: Elementos para una integración conceptual. Revista Latinoamericana de Psicología, 39(2), 351-361.

Parsons, T. (2013). The Social System. New York: Routledge.

Penrose, E. T. (2003). The Theory of the Growth of the Firm. http://dx.doi.org/10.1093/0198289774.003.0002

Piñones, V. S., Acosta, A. L. A., \& Tartanac, F. (2006). Alianzas Productivas en Agrocadenas (1 st ed.). Santiago, Chile: Oficina Regional de la FAO para América Latina y el Caribe.

Powell, W. (2003). Neither market nor hierarchy. Network forms of organization. In M. J. Handel (Ed.), The sociology of organizations: Classic, contemporary, and critical readings (pp. 315-330). United Kindom: SAGE Publications.

Puduri, V. S., Govindasamy, R., Myers, J. J., \& O’Dierno, L. J. (2011). Consumer attitude towards pricing of live aquatic products. Aquaculture Economics \& Management, 15(2), 118-129. http://dx.doi.org/10.1080/ 13657305.2011.573522

Rangel-López, L., Lango-Reynoso, F., Asian-Hoyos, A., \& Castañeda-Chávez, M. de R. (2014). Diagnóstico de la acuacultura en el municipio de Alvarado, Veracruz, México. Ra Ximhai, 10(6), 75-81.

Reta, M. J. L., Luna, F. J., Zetina, C. P., Suarez, S. C., Mena, G. J. M., \& Ramos, H. A. (2007). Programa Maestro Tilapia para el Estado de Veracruz. México: SAGARPA. 
Reta, M. J. L., Mena, G. J. M., Asiain, H. A., \& Suarez, S. C. (2011). Manual de procesos de innovación rural (PIR) en la acuacultura. México: Colegio de Postgraduados.

Rodríguez, G. M. G. (1999). Las particularidades de la globalización de la leche: una propuesta de análisis. In B. E. Martínez, A. M. A., H. L. A. García \& M. de C. Del Valle (Eds.), Dinámica del sistema lechero mexicano en el marco regional y global (1st ed., pp. 87-125). México: Plaza y Valdes.

Rugman, A. M., \& Verbeke, A. (2002). Edith Penrose's contribution to the Resource-Based View of Strategic Management. Strategic Management Journal, 23, 769-780. http://dx.doi.org/10.1002/smj.240

Sankaran, J. K., \& Suchitra, M. V. (2006). Value-chain innovation in aquaculture: Insights from a New Zealand case study. $R \& D$ Management, 36(4), 387-401. http://dx.doi.org/10.1111/j.1467-9310.2006.00441.x

SAT, SE, Banco de México, \& INEGI. (2016). Balanza Comercial de Mercancías de México. SNIEG, Información de Interés Nacional. Retrieved June 10, 2016, from http://www.banxico.org.mx/SieInternet/ consultarDirectorioInternetAction.do?accion $=$ consultarCuadro\&idCuadro $=\mathrm{CE} 122 \&$ sector $=1 \&$ locale $=\mathrm{es}$

Sautu, R., Boniolo, P., Dalle, P., \& Elbert, R. (2005). Manual de metodología: Construcción del marco teórico, formulación de los objetivos y elección de la metodología. Buenos Aires: CLACSO.

Schwartz, S. H. (2003). A proposal for measuring value orientations across nations. Questionnaire Package of the European Social Survey (pp. 259-290).

Schwartz, S. H. (2006). A theory of cultural value orientations: Explication and applications. Comparative Sociology, 5(2), 137-182. http://dx.doi.org/10.1163/ej.9789004170346.i-466.55

SHCP. (2016). Transparencia presupuestaria. Retrieved February 25, 2016, from http://transparenciapresupue staria.gob.mx/es/PTP/SED

Soosay, C. A., Hyland, P. W., \& Ferrer, M. (2008). Supply chain collaboration: Capabilities for continuous innovation. Supply Chain Management: An International Journal, 13(2), 160-169. http://dx.doi.org/ 10.1108/13598540810860994

Sykuta, M. E., \& Chaddad, F. R. (1999). Putting theories of the firm in their place: A supplemental digest of the new institutional economics. Journal of Cooperatives, 14(1), 68-76.

Tallec, F., \& Bockel, L. (2005). Commodity Chain Analysis. Constructing the Commodity Chain: Functional Analysis and Flow Charts. Rome: FAO.

Teece, D., \& Pisano, G. (1994). The dynamic capabilities of firms: An introduction. Industrial and Corporate Change, 3(3), 537-556. http://dx.doi.org/10.1093/0198290969.003.0006

Thapa, G., Dey, M. M., \& Engle, C. (2015). Consumer Preferences for Live Seafood in the Northeastern Region of USA: Results from Asian Ethnic Fish Market Survey. Aquaculture Economics \& Management, 19(2), 210-225. http://dx.doi.org/10.1080/13657305.2015.1024346

Thorpe, A., \& Bennett, E. (2004). Market-driven international fish supply chains: The case of Nile perch from Africa's Lake Victoria. International Food and Agribusiness Management Review, 7(4), 40-57.

Vigorito, R. (1977). Criterios Metodológicos para el Estudio de Complejos Agroindustriales. México: ILET

Vivanco, A. M., Martínez, C. F. J., \& Taddei, B. I. C. (2010). Análisis de competitividad de cuatro sistema-producto estatales de tilapia en México. Estudios Sociales, 18(35), 165-207. http://dx.doi.org/ 10.1016/j.techfore.2010.05.005

Watanabe, W. O., Losordo, T. M., Fitzsimmons, K., \& Hanley, F. (2002). Tilapia production systems in the Americas: technological advances, trends, and challenges. Reviews in Fisheries Science, 10(3-4), 465-498. http://dx.doi.org/10.1080/20026491051758

Williamson, O. E. (1994). La Organización del Trabajo: Un Enfoque Institucional Comparativo. In L. Putterman (Ed.), La Naturaleza Económica de la Empresa (pp. 361-384). España: Alianza Editorial.

Williamson, O. E. (2009). In E. L. Suárez (Trans.), Las Instituciones Económicas del Capitalismo. México: Fondo de Cultura Económica.

Willke, H. (1993). Systemtheorie entwickelter Gesellschaften: Dynamik und Riskanz moderner gesellschaftlicher Selbstorganisation. Grundlagentexte Soziologie. München: Juventa Verlag.

Young, J. A., \& Muir, J. F. (2002). Tilapia: Both fish and fowl? Marine Resource Economics, 17(2), 163-173. http://dx.doi.org/10.1086/mre.17.2.42629359 


\section{Notes}

Note 1. According to the expense reports Productivity Promotion Program for Fisheries and Aquaculture.

Note 2. Based on national figures of apparent consumption (15 $3011 \mathrm{t}$ ), production (96 $827 \mathrm{t}$ ), and imports (54 $859 \mathrm{t}$ ), it is estimated that in the state 30,474 tons of tilapia have been consumed, of which only $63 \%$ are state produced, assuming that $100 \%$ of the production is consumed locally, although there is evidence that at least $4 \%$ of the production goes to other states.

Note 3. Imports of Chinese tilapia started in 2004 and have grown $245 \%$ since that time.

Note 4. Under the Law of Sustainable Rural Development, the Production System Committee is the governing body making decisions and promoting actions to favor the competitiveness of domestic aquaculture activities.

Note 5. Luhmann conceives the collective memory as a set of memories and expectations of the social system, the result of communication system operations evaluated positively or negatively.

Note 6. Technological, economic, and market management have been considered as the basis for the competitiveness of Mexican aquaculture chains.

Note 7. The neoclassical economic paradigm, focused on maximizing economic gains, is based on a free market, perfect competition and zero state participation.

Note 8. The term globalization is a neologism referring to the expansion of an economic development system based on the quantitative theory of money that proclaims interest in the value of money and incentives to develop the market.

Note 9. Considering the scarcity of natural resources, climate change, health risks, economic uncertainty, the use of inappropriate technology, and market problems.

Note 10. Including the theory of transaction costs proposed by R. Coase in 1937 in his book The Nature of the Firm and developed by Kenneth Arrow in 1973 in his general equilibrium model.

Note 11. Where forms of client-provider organization are proposed.

Note 12. In the case of consumer links, the elements are consumer families.

Note 13. The management body is a command structure (governance) organized through the conduct of companies, which is formed by their habits and rules.

Note 14. Considering attributes, frequency and intensity.

Note 15. The company, hybrid relationships, or the market.

Note 16. These systems are companies, cooperatives, civil associations, state services, and non-governmental organizations.

Note 17. The values of a collectivist society focus on the interests of the entire community.

Note 18. The values of an individualistic society focus on development and personal success.

Note 19. From breaking traditional commercial agreements.

Note 20. For this work, competitiveness is the ability of an agricultural value chain to maintain itself and grow over time, a market share of its main product, and this is derived from the implementation by its management team of specific mechanisms for efficient management of their heterogeneous internal and external resources, the utilization of their productive opportunities, and the development of their learning abilities and accumulation of knowledge. Thus, they can respond to changes in the environment; which contributes to the permanence and economic growth of its actors through the creation of value between links in the chain.

Note 21. A psychic system is a system of awareness, which from the chain approach, is composed of the actors who control the links in the agrifood-chain.

Note 22. Social capital is seen as an attribute of individuals and their relationships that improves their ability to solve problems needing collective action (Ostrom and Ahn, 2009). This form of shared norms, common knowledge and rules of use regarding an institutional arrangement are used to solve common dilemmas (Ostrom et al., 2003).

Note 23. Understood and organized as an institution. 


\section{Appendix}

Appendix A. Characterization of Tilapia Agrifood-Chain

\begin{tabular}{|c|c|c|c|c|c|c|c|c|}
\hline Model & Approach & Structure & Function & $\begin{array}{l}\text { Management } \\
\text { Approach }\end{array}$ & Product & Prices & $\begin{array}{l}\text { Production } \\
\text { Systems }\end{array}$ & $\begin{array}{l}\text { Type of } \\
\text { Business }\end{array}$ \\
\hline Supply chain & $\begin{array}{l}\text { Global } \\
\text { logistics } \\
\text { management }\end{array}$ & $\begin{array}{l}\text { Network } \\
\text { services and } \\
\text { integrated } \\
\text { distribution } \\
\text { options for } \\
\text { multiple agents }\end{array}$ & $\begin{array}{l}\text { Procurement } \\
\text { of materials, } \\
\text { processing of } \\
\text { these } \\
\text { materials into } \\
\text { intermediate } \\
\text { and finished } \\
\text { products, and } \\
\text { distribution to } \\
\text { customers }\end{array}$ & $\begin{array}{l}\text { Facilitating } \\
\text { communication, } \\
\text { efficient exchange } \\
\text { of information } \\
\text { and knowledge, } \\
\text { coordinated } \\
\text { decisions, } \\
\text { cooperative work, } \\
\text { integrated } \\
\text { activities }\end{array}$ & $\begin{array}{l}\text { Quantity and } \\
\text { quality with } \\
\text { international } \\
\text { standards } \\
\text { focused on } \\
\text { high } \\
\text { consumption } \\
\text { items (whole } \\
\text { fish and frozen } \\
\text { fillets) }\end{array}$ & $\begin{array}{l}\text { Low } \\
\text { international } \\
\text { prices }\end{array}$ & $\begin{array}{l}\text { Intensive } \\
\text { systems }\end{array}$ & $\begin{array}{l}\text { Large scale } \\
\text { with high } \\
\text { technology } \\
\text { development }\end{array}$ \\
\hline Value chain & $\begin{array}{l}\text { Global } \\
\text { business }\end{array}$ & $\begin{array}{l}\text { Joint companies } \\
\text { linked by flows } \\
\text { of information, } \\
\text { materials, and } \\
\text { financial and } \\
\text { service funtions } \\
\text { for special } \\
\text { products }\end{array}$ & $\begin{array}{l}\text { Add value to } \\
\text { the product or } \\
\text { service along } \\
\text { the links of } \\
\text { economic } \\
\text { agents ranging } \\
\text { from } \\
\text { production to } \\
\text { consumption }\end{array}$ & $\begin{array}{l}\text { Establishing } \\
\text { business } \\
\text { relationships } \\
\text { (hierarchical } \\
\text { alliances or } \\
\text { strategic } \\
\text { networks), } \\
\text { efficiency in } \\
\text { resource use }\end{array}$ & $\begin{array}{l}\text { Quantity and } \\
\text { quality with } \\
\text { international } \\
\text { standards } \\
\text { focused on } \\
\text { products } \\
\text { differentiated } \\
\text { by having high } \\
\text { added value } \\
\text { (live fish, fresh } \\
\text { fillets) }\end{array}$ & $\begin{array}{l}\text { High } \\
\text { international } \\
\text { and } \\
\text { domestic } \\
\text { prices }\end{array}$ & $\begin{array}{l}\text { Intensive } \\
\text { systems }\end{array}$ & $\begin{array}{l}\text { Large and } \\
\text { medium scal } \\
\text { with high } \\
\text { technology } \\
\text { development }\end{array}$ \\
\hline $\begin{array}{l}\text { Production } \\
\text { chain }\end{array}$ & $\begin{array}{l}\text { Sectorial } \\
\text { agribusiness }\end{array}$ & $\begin{array}{l}\text { Links } \\
\text { interconnected } \\
\text { by flows of } \\
\text { energy, capital, } \\
\text { materials, and } \\
\text { information, all } \\
\text { integrated by } \\
\text { agents related to } \\
\text { a production } \\
\text { process }\end{array}$ & $\begin{array}{l}\text { Process of } \\
\text { materials into } \\
\text { a final product } \\
\text { for delivery to } \\
\text { consumers }\end{array}$ & $\begin{array}{l}\text { Coordination of } \\
\text { actors and } \\
\text { activities }\end{array}$ & $\begin{array}{l}\text { Quantity and } \\
\text { quality of } \\
\text { variables } \\
\text { focused on a } \\
\text { fresh whole } \\
\text { products }\end{array}$ & $\begin{array}{l}\text { Low } \\
\text { domestic } \\
\text { and regional } \\
\text { prices }\end{array}$ & $\begin{array}{l}\text { Semi-intensive } \\
\text { and extensive } \\
\text { systems }\end{array}$ & $\begin{array}{l}\text { Medium and } \\
\text { small-scale } \\
\text { with medium } \\
\text { and } \\
\text { small-scale } \\
\text { technology } \\
\text { development }\end{array}$ \\
\hline
\end{tabular}

\section{Copyrights}

Copyright for this article is retained by the author(s), with first publication rights granted to the journal.

This is an open-access article distributed under the terms and conditions of the Creative Commons Attribution license (http://creativecommons.org/licenses/by/4.0/). 